Australian Journal of

Crop Science

AJCS

AJCS 13(09):1495-1502 (2019)

ISSN:1835-2707

doi: 10.21475/ajcs.19.13.09.p1628

\title{
Genetic analysis of nutritional and antioxidant traits in eggplant (S. melongena)
}

\author{
N. T Afful* ${ }^{* 1,2}$, D. Nyadanu ${ }^{1}$, R Akromah ${ }^{1}$, H. M Amoatey, S. Amiteye, C. Annor ${ }^{2}$ \\ ${ }^{1}$ Department of Plant and Soil Sciences, Kwame Nkrumah University of Science and Technology, Kumasi, Ghana \\ ${ }^{2}$ Department of Plant and Soil Sciences, Biotechnology and Nuclear Agriculture Research Institute, Ghana Atomic \\ Energy Commission, Legon, P. O. Box 80, Accra, Ghana
}

*Corresponding author: enusrat@yahoo.com

\begin{abstract}
Six generations of eggplants (P1, P2, F1, F2, BC1 and BC2) obtained from two crosses SM001-07 x ST004-03 and SM001-07 x San005-01 were grown in an open field using Randomized complete Block Design with four replications. The experiment was conducted to determine gene effects for the inheritance of twelve nutritional and antioxidant traits in eggplant using generation mean analysis. The analysis of variance showed significant differences for most traits indicating the presence of sufficient variation in the eggplant materials under study. Additive-dominance effect was adequate to demonstrate the genetic variation and its significance in the inheritance of protein and magnesium contents, while non-allelic interactions were observed to be important for iron, zinc and total phenol in both crosses. The study also showed low values for dominance and environmental variances that resulted in high heritability values for most traits. Therefore, to improve these traits population improvement approaches (recurrent selection or pure line) followed by delayed selection in segregating generation would yield better results.
\end{abstract}

Keywords: Antioxidant; eggplant; gene effects; heritability; proximate; minerals.

\section{Introduction}

To combat the increasing rate of nutrient deficiencies in the diets of over a billion people in developing countries; the consumption of fruits and vegetable has been proposed as an alternative source of nutrient. Diets rich in fruits and vegetables have been reported to be highly correlated with better health and disease prevention (Lobo et al., 2010; Boeing et al., 2012), owing to the high levels of minerals, vitamins and bioactive compounds in these dietary components.

Eggplant ( $S$. melongena), is an important solanaceous, vegetable crop cultivated throughout the world for its edible fruits and leaves (Deshmukh et al., 2014). In Ghana, the crop is consumed as a fruit and or leafy vegetable for its essential nutrients (minerals and vitamins) and antioxidants. However, majority of cultivated eggplant varieties in the country are landraces with low nutrient composition compared to their wild relatives (Denton and Nwangburuka, 2011). Further, these local varieties have not been fully exploited by way of genetic improvement of fruit quality traits. Interspecific hybridization involving related local varieties and their wild relatives may produce hybrids with high nutrient levels which are adapted to the local environment. These would meet consumer preference and therefore command higher market value.
For a successful improvement of nutritional and antioxidant traits in eggplant breeding, information concerning the nature and magnitude of genes controlling these traits is of prime importance. Evaluating the type of genes and their interactions in a plant population is necessary to decide the type of breeding method to be adopted (Deb and Khaleque, 2009; Arora et al., 2010). Generation mean analysis is one of the genetic models that can be used to estimate the various gene effects (Kearsey and Pooni, 1996): additive, dominance and non-allelic interactions gene effects (additive $\times$ additive, dominance $x$ dominance and additive $x$ dominance effects (Singh and Singh, 1992). Moreover, the magnitude of genetic variation within the population determines the extent of variation that is heritable. This is because the efficiency of selection mainly depends on additive genetic variance, influence of the environment and interaction between genotype and environment (Sumanth et al., 2017).

Although, a lot has been done towards the improvement of eggplant leading to the release of several eggplant varieties in other countries, the same cannot be said about Ghana, especially concerning improvement of nutritional and antioxidant traits. The study sought to provide information needed to estimate genetic parameters controlling nutritional and antioxidant traits in eggplant as well as estimate variance components and heritability of these traits by means of the six 
populations ( $\mathrm{P} 1, \mathrm{P} 2, \mathrm{~F} 1, \mathrm{~F} 2, \mathrm{BC} 1$ and $\mathrm{BC} 2)$ derived from two crosses.

\section{Results}

\section{Mean values of proximate, mineral and antioxidant traits}

Tables 1 and 2 show mean values and standard errors of carbohydrate, dry matter, moisture, fibre, protein, copper, iron, potassium, magnesium, zinc, total phenols and antioxidant concentrations for six basic generations obtained from two crosses, SM001-07 $\times$ ST004-03 and SM001-07 $x$ San005-01, respectively. The results show significant differences $(p \leq 0.05)$ among generations of both crosses for all the traits except protein, fibre, total phenol and potassium (SM001-07 x San005-01) (Table 1).

Among the three parents, the wild genotypes used as donor parents (ST004-03 and San005-01) exhibited higher concentrations of all traits studied compared to the local variety (recurrent parent - SM001-07) except for carbohydrate $(4.96 \mathrm{~g} / 100 \mathrm{~g})$, moisture $(90.48 \%)$ and fibre $(1.53 \mathrm{~g} / 100 \mathrm{~g})$ which were higher in the latter. The recurrent parent also showed higher mean values for potassium $(2.20 \mathrm{mg} / 100 \mathrm{~g})$ and total phenols (176.30mgGAE/g) compared to the donor parents (Tables 1 and 2). Of the F1 generations, the mean values recorded for both crosses were generally lower than the mean values for either parent (P1 or P2), except for fibre, protein and potassium which were higher than the mean values for both parents (Tables 1 and 2). The mean values for carbohydrate and magnesium were also higher compared to the average values for both parents. However, the concentration of copper $(1.86 \mathrm{mg} / 100 \mathrm{~g})$ and antioxidant content $(864.71 \mathrm{mg} / \mathrm{g})$ in cross SM001-07 x ST004-03 was significantly lower $(p \geq 0.05)$ than the values of copper for both parents (Table 1).

Further, the mean values of both $\mathrm{F} 1$ generations for most traits were higher compared to those of the two F2 generations, except for copper, potassium, antioxidant content (SM001-07 $x$ ST004-03), carbohydrate and dry matter (SM001-07 $x$ San005-01) which showed higher mean values in F2 than F1 generations (Tables 1 and 2). The mean values of the F2 generation obtained from the crosses SM001-07 x ST004-03 and SM001-07 $\times$ San005-01 were higher than the mean values recorded for the parental genotypes (P1 and P2) for the traits potassium, protein and magnesium.

Again by comparison, the mean values observed for the F1 generations (both crosses) were higher than the mean values for the BC1 generations (both crosses) for most traits apart from antioxidant content, carbohydrate, fibre, copper and zinc. However, mean values for traits in F2 generations (both crosses) showed lower values than those obtained in $\mathrm{BC} 2$ generations except for fibre, copper, potassium, magnesium, carbohydrate and antioxidant content (Tables 1 and 2). Moreover, the $\mathrm{BC} 1$ generations in both crosses showed lower mean values compared to $\mathrm{BC} 2$ generations excluding moisture, fibre, copper (SM001-07 x ST004-03) carbohydrate, moisture, protein, potassium and magnesium (SM001-07 x San005-01).

Finally, the mean values recorded for zinc, magnesium, antioxidant content (both crosses), potassium, total phenols
(SM001-07 x ST004-03), protein, dry matter and iron (SM001$07 \times$ San005-01) in BC2 generations were significantly higher $(p \leq 0.05)$ than the corresponding values observed for the recurrent parent (Tables 1 and 2).

\section{Gene action for nutritional and antioxidant characters}

The gene effect of crosses SM001-07 x ST004-03 and SM001$07 \times$ San005-01 for nutrient composition and antioxidant content are presented in Tables 3 and 4 . The expected mean $(\mathrm{m})$ in both crosses was positive and significant $(P<0.05)$ for all the traits under study. In the cross SM001-07 x ST004-03, additive gene effect was negative and significant for all traits, except dry matter and copper, while dominance effect was positive and significant except for potassium and copper. Also dominance effect was greater than additive effect for all traits excluding potassium, magnesium and zinc (Tables 3 and 4). Among the interaction gene effects, the additive $x$ additive effect was generally greater than either additive $x$ dominance effect or dominance $x$ dominance effect except copper (SM001-07 x ST004-03), magnesium (both crosses), dry matter and antioxidant content (SM001-07 x San005-01) (Tables 3 and 4).

In cross SM001-07 x San005-01, additive gene effect was positive and significant for most traits. However, negative and significant gene effect was observed for dry matter, iron, zinc and antioxidant content. Dominance gene effect showed positive and significant effect for all traits, apart from antioxidant content, zinc, copper, dry matter and carbohydrate. Further, dominance gene effect was higher than additive effect for all traits studied except for carbohydrate, dry matter, copper, zinc and antioxidant content. With regard to gene interaction effects, additive $x$ dominance gene effect was greater than additive $x$ additive and dominance $x$ dominance gene effects put together for carbohydrate, protein, dry matter, moisture, fibre and potassium (Tables 3 and 4).

Carbohydrate was found positive and significant for dominance gene effect as well as additive $\mathrm{x}$ additive interaction effect in cross SM001-07 x ST004-03, while a positive and significant additive gene effect was observed in SM001-07 x San005-01 (Tables 3 and 4). Negative and significant additive gene effect was observed in both crosses for dry matter. Cross SM001-07 x ST004-03 showed a positive and significant dominance and additive $x$ additive gene interaction effect while a positive and significant additive $x$ dominance interaction effect was observed in SM001-07 $x$ San005-01 (Tables 3 and 4).

The gene action for 'moisture' trait was positive and significant for main gene effects (additive and dominance) as well as additive $x$ additive interaction gene effects in both crosses (Tables 4 and 5). The additive $x$ dominance gene interaction effect was also observed to be significant but negative for the same trait (Tables 4 and 5).

Positive and significant additive gene effect was observed for fibre in crosses SM001-07 x ST004-03 and SM001-07 x San00501 . However, positive and significant dominance gene effect was recorded only in cross SM001-07 x San005-01 (Tables 4 and 5). 
Table 1. Comparisons of means ( \pm SE) for nutritional and antioxidant traits of cross SM001-07 (S. melongena) x ST004-03 (S. torvum).

\begin{tabular}{|c|c|c|c|c|c|c|c|}
\hline & & & Populations & & & & \\
\hline Trait & P1 & P2 & F1 & F2 & BC1 & $\mathrm{BC} 2$ & CV \\
\hline Carbohydrate & $4.96 \pm 0.83^{\mathrm{cd}}$ & $4.73 \pm 0.74^{b c}$ & $5.24 \pm 0.81^{d}$ & $4.13 \pm 0.83^{a}$ & $4.60 \pm 0.90^{b}$ & $4.70 \pm 1.28^{b c}$ & 2.5 \\
\hline Dry matter & $1.31 \pm 1.14^{\mathrm{a}}$ & $1.96 \pm 1.03^{c}$ & $1.42 \pm 1.19^{\mathrm{ab}}$ & $1.23 \pm 0.81^{\mathrm{a}}$ & $1.23 \pm 0.84^{\mathrm{a}}$ & $1.52 \pm 0.24^{b}$ & 4.8 \\
\hline Moisture & $90.48 \pm 0.92^{d}$ & $81.46 \pm 0.80^{\mathrm{a}}$ & $90.33 \pm 2.46^{d}$ & $85.44 \pm 2.32^{b}$ & $87.40 \pm 2.52^{\mathrm{c}}$ & $86.48 \pm 2.09^{b c}$ & 0.8 \\
\hline Fibre & $1.53 \pm 0.83^{b}$ & $0.92 \pm 0.22^{\mathrm{a}}$ & $1.57 \pm 0.97^{b}$ & $1.42 \pm 0.76^{\mathrm{b}}$ & $1.44 \pm 0.83^{b}$ & $1.42 \pm 0.84^{b}$ & 11.7 \\
\hline Protein & $1.78 \pm 0.83^{b}$ & $1.82 \pm 0.83^{a}$ & $2.23 \pm 0.70^{c}$ & $1.75 \pm 0.83^{b}$ & $1.78 \pm 0.83^{b}$ & $1.93 \pm 0.83^{b}$ & 4.8 \\
\hline Copper & $2.06 \pm 0.83^{\mathrm{cd}}$ & $2.06 \pm 0.7^{c d}$ & $1.86 \pm 0.83^{b}$ & $1.98 \pm 0.77^{\mathrm{bc}}$ & $2.14 \pm 0.88^{d}$ & $1.82 \pm 0.81^{\mathrm{a}}$ & 2.6 \\
\hline Iron & $4.60 \pm 0.83^{a}$ & $5.46 \pm 0.84^{c}$ & $5.32 \pm 0.83^{b c}$ & $4.78 \pm 0.84^{\mathrm{ab}}$ & $4.92 \pm 0.70^{a b c}$ & $5.05 \pm 0.70 \mathrm{abc}$ & 4.5 \\
\hline Potassium & $2.77 \pm 0.83^{\mathrm{a}}$ & $3.21 \pm 0.80^{c}$ & $3.26 \pm 0.60^{c}$ & $3.33 \pm 0.73^{\mathrm{cd}}$ & $2.95 \pm 0.81^{b}$ & $3.50 \pm 0.70^{d}$ & 2.8 \\
\hline Magnesium & $2.51 \pm 0.81^{a}$ & $5.26 \pm 0.86^{\mathrm{bc}}$ & $4.32 \pm 0.84^{c}$ & $4.10 \pm 0.30^{\mathrm{bc}}$ & $3.98 \pm 0.81^{b}$ & $4.02 \pm 0.83^{d}$ & 0.1 \\
\hline Zinc & $0.46 \pm 0.22^{\mathrm{a}}$ & $1.86 \pm 0.83^{d}$ & $0.99 \pm 0.26^{\mathrm{bc}}$ & $0.88 \pm 0.26^{b}$ & $0.87 \pm 0.26^{b}$ & $1.02 \pm 0.22^{c}$ & 4.6 \\
\hline Total phenols & $199.27 \pm 8.80^{\mathrm{b}}$ & $221.11 \pm 7.76^{\mathrm{e}}$ & $208.61 \pm 7.62^{c}$ & $183.78 \pm 9.63^{\mathrm{a}}$ & $176.07 \pm 8.16^{\mathrm{a}}$ & $219.88 \pm 7.73^{d}$ & 0.4 \\
\hline Ant. Content & $897.18 \pm 7.74^{b}$ & $1377.77 \pm 2.99^{f}$ & $864.71 \pm 15.43^{\mathrm{a}}$ & $1039.32 \pm 19.14^{d}$ & $983.00 \pm 7.10^{c}$ & $1093.11 \pm 1.83^{\mathrm{e}}$ & 0.2 \\
\hline
\end{tabular}

P1 - recurrent parent, P2 - donor parent, F1- first filial generation, F2 - second filial generation, BC1- backcross one generation, BC2 - backcross one generation. Means followed by different letters in the same row are significantly different according to Tukey test at $\mathrm{p} \leq 0.05$.

Table 2. Comparisons of means ( \pm SE) for nutritional and antioxidant traits of cross SM001-07 (S. melongena) x San005-01 (S. anguivi).

\begin{tabular}{|c|c|c|c|c|c|c|c|}
\hline \multicolumn{8}{|c|}{ Populations } \\
\hline Trait & P1 & P2 & F1 & F2 & BC1 & BC1 & CV \\
\hline Carbohydrate & $4.96 \pm 0.84^{b}$ & $2.40 \pm 0.8^{\mathrm{a}}$ & $3.06 \pm 0.96^{\mathrm{a}}$ & $3.36 \pm 1.01^{\mathrm{a}}$ & $3.32 \pm 0.76^{\mathrm{a}}$ & $3.21 \pm 1.03^{\mathrm{a}}$ & 2.4 \\
\hline Dry matter & $1.20 \pm 0.76^{\mathrm{a}}$ & $3.911 \pm 0.95^{\mathrm{c}}$ & $2.36 \pm 0.54^{b}$ & $2.49 \pm 0.96^{b}$ & $2.30 \pm 1.01^{b}$ & $2.62 \pm 0.78^{b}$ & 2.7 \\
\hline Moisture & $90.04 \pm 0.2^{c}$ & $62.01 \pm 2.24^{\mathrm{a}}$ & $80.22 \pm 2.65^{b c}$ & $72.66 \pm 2.99^{\mathrm{ab}}$ & $77.43 \pm 4.01^{\mathrm{b}}$ & $73.88 \pm 4.28^{\mathrm{ab}}$ & 1.7 \\
\hline Fibre & $1.53 \pm 0.83^{\mathrm{a}}$ & $0.94 \pm 0.22^{\mathrm{a}}$ & $1.65 \pm 1.00^{\mathrm{a}}$ & $1.22 \pm 0.90^{\mathrm{a}}$ & $1.34 \pm 0.84^{\mathrm{a}}$ & $1.37 \pm 0.83^{\mathrm{a}}$ & 4.7 \\
\hline Protein & $1.78 \pm 0.84^{\mathrm{a}}$ & $1.98 \pm 0.7^{\mathrm{a}}$ & $2.33 \pm 0.83^{\mathrm{a}}$ & $1.99 \pm 0.83^{\mathrm{a}}$ & $2.10 \pm 0.70^{\mathrm{a}}$ & $2.03 \pm 0.70^{\mathrm{a}}$ & 2.5 \\
\hline Copper & $2.73 \pm 0.83^{\mathrm{ab}}$ & $3.65 \pm 0.74^{b}$ & $2.70 \pm 0.88^{\mathrm{a}}$ & $2.50 \pm 0.83^{\mathrm{a}}$ & $2.60 \pm 0.77^{\mathrm{a}}$ & $2.90 \pm 0.70^{\mathrm{ab}}$ & 2.2 \\
\hline Iron & $4.60 \pm 0.82^{b}$ & $11.21 \pm 1.06^{d}$ & $8.25 \pm 0.70^{\mathrm{a}}$ & $6.21 \pm 0.74^{c}$ & $7.83 \pm 0.83^{\mathrm{a}}$ & $8.35 \pm 1.05^{a}$ & 1.6 \\
\hline Potassium & $2.77 \pm 0.82^{\mathrm{a}}$ & $2.20 \pm 0.72^{\mathrm{a}}$ & $2.91 \pm 0.72^{\mathrm{a}}$ & $2.61 \pm 0.76^{a}$ & $2.70 \pm 0.67^{\mathrm{a}}$ & $2.60 \pm 0.76^{a}$ & 2.8 \\
\hline Magnesium & $0.13 \pm 0.28^{c}$ & $0.15 \pm 0.26^{\mathrm{a}}$ & $0.47 \pm 0.42^{b}$ & $0.33 \pm 0.41^{b}$ & $0.33 \pm 0.57^{b c}$ & $0.32 \pm 0.22^{b c}$ & 2.7 \\
\hline Zinc & $0.80 \pm 0.70^{\mathrm{a}}$ & $3.93 \pm 0.70^{d}$ & $2.82 \pm 0.70^{\mathrm{bc}}$ & $2.57 \pm 0.67^{b}$ & $2.95 \pm 0.70^{b}$ & $3.00 \pm 1.05^{c}$ & 2.4 \\
\hline Total phenols & $188.18 \pm 7.07^{\mathrm{a}}$ & $176.30 \pm 7.08^{\mathrm{a}}$ & $181.28 \pm 7.75^{a}$ & $167.79 \pm 6.64^{a}$ & $170.28 \pm 6.26^{\mathrm{a}}$ & $177.88 \pm 7.76^{a}$ & 2.2 \\
\hline Ant. Content & $908.30 \pm 7.07^{a}$ & $1474.00 \pm 6.56^{d}$ & $979.11 \pm 9.37^{b}$ & $965.21 \pm 7.75^{b}$ & $974.40 \pm 7.10^{b}$ & $1062.00 \pm 2.24^{c}$ & 2.2 \\
\hline
\end{tabular}

according to Tukey test at $p \leq 0.05$.

Table 3. Estimate of gene effects on nutritional and antioxidant traits of the cross SM001-07 x ST004-03.

\begin{tabular}{|c|c|c|c|c|c|c|}
\hline Trait & $\mathrm{m}$ & $a$ & d & aa & ad & dd \\
\hline Carbohydrate & $3.04 \pm 0.10^{*}$ & $0.11 \pm 0.03$ & $2.20 \pm 0.13^{*}$ & $1.80 \pm 0.11^{*}$ & $-0.28 \pm 0.23$ & $-0.09 \pm 0.77$ \\
\hline Dry matter & $1.03 \pm 0.01^{*}$ & $-0.32 \pm 0.00 *$ & $0.38 \pm 0.01 *$ & $0.60 \pm 0.01^{*}$ & $0.07 \pm 0.01$ & $0.09 \pm 0.13$ \\
\hline Moisture & $80.67 \pm 0.35 *$ & $4.50 \pm 0.01^{*}$ & $9.71 \pm 0.48^{*}$ & $5.29 \pm 0.35^{*}$ & $-7.30 \pm 0.44^{*}$ & $-6.30 \pm 1.67$ \\
\hline Fibre & $1.27 \pm 0.06^{*}$ & $0.30 \pm 0.01^{*}$ & $0.30 \pm 0.08$ & $-0.04 \pm 0.06$ & $-0.55 \pm 0.08$ & $-0.20 \pm 1.31$ \\
\hline Protein & $1.25 \pm 0.06^{*}$ & $-0.01 \pm 0.02$ & $0.96 \pm 0.08 *$ & $0.54 \pm 0.06$ & $-0.26 \pm 0.09$ & $0.27 \pm 0.56$ \\
\hline Copper & $2.11 \pm 0.01 *$ & $0.01 \pm 0.00$ & $-0.24 \pm 0.02$ & $-0.04 \pm 0.01$ & $0.62 \pm 0.03 *$ & $0.13 \pm 1.41$ \\
\hline Iron & $4.24 \pm 0.01^{*}$ & $-0.43 \pm 0.01 *$ & $1.07 \pm 0.02 *$ & $0.78 \pm 0.02 *$ & $0.60 \pm 0.02 *$ & $-0.06 \pm 1.51$ \\
\hline Potassium & $3.39 \pm 0.01^{*}$ & $-0.22 \pm 0.00 *$ & $-0.13 \pm 0.01^{*}$ & $-0.40 \pm 0.01^{*}$ & $-0.65 \pm 0.01^{*}$ & $-0.26 \pm 1.38$ \\
\hline Magnesium & $3.94 \pm 0.14^{*}$ & $-1.37 \pm 0.10^{*}$ & $0.32 \pm 0.27$ & $-0.07 \pm 0.16$ & $2.65 \pm 0.43$ & $0.63 \pm 5.23$ \\
\hline Zinc & $0.76 \pm 0.01^{*}$ & $-0.68 \pm 0.04^{*}$ & $0.23 \pm 0.02$ & $0.38 \pm 0.04$ & $0.96 \pm 0.05^{*}$ & $-1.51 \pm 0.75$ \\
\hline Total phenols & $161.35 \pm 3.22 *$ & $-10.86 \pm 1.01 *$ & $47.51 \pm 3.98^{*}$ & $49.03 \pm 3.51^{*}$ & $-66.14 \pm 4.20^{*}$ & $-25.86 \pm 2.41$ \\
\hline Anti. Content & $1264.76 \pm 13.60 *$ & $-247.58 \pm 12.92 *$ & $-394.049 \pm 16.31$ & $-119.79 \pm 16.02$ & $273.86 \pm 15.05$ & $-369.65 \pm 7.04$ \\
\hline
\end{tabular}

Table 4. Estimate of gene effects on nutritional and antioxidant traits of the cross SM001-07 x San005-01.

\begin{tabular}{|c|c|c|c|c|c|c|}
\hline Trait & $\mathrm{m}$ & $a$ & $\mathrm{~d}$ & aa & ad & $\mathrm{dd}$ \\
\hline Carbohydrate & $3.53 \pm 0.24^{*}$ & $1.27 \pm 0.05^{*}$ & $-0.49 \pm 0.32$ & $0.13 \pm 0.25$ & $-2.45 \pm 0.29$ & $1.17 \pm 1.89$ \\
\hline Dry matter & $2.60 \pm 0.02 *$ & $-1.35 \pm 0.01^{*}$ & $-0.24 \pm 0.02$ & $-0.05 \pm 0.02$ & $2.06 \pm 0.03^{*}$ & $1.54 \pm 0.33$ \\
\hline Moisture & $65.21 \pm 0.37 *$ & $14.01 \pm 0.05^{*}$ & $15.02 \pm 0.45^{*}$ & $10.80 \pm 0.45^{*}$ & $-20.82 \pm 0.98 *$ & $3.36 \pm 4.50$ \\
\hline Fibre & $0.81 \pm 0.05^{*}$ & $0.29 \pm 0.01 *$ & $0.85 \pm 0.07^{*}$ & $0.42 \pm 0.05$ & $-0.65 \pm 0.06$ & $-0.29 \pm 1.71$ \\
\hline Protein & $1.67 \pm 0.04 *$ & $-0.09 \pm 0.01$ & $0.66 \pm 0.05^{*}$ & $0.21 \pm 0.04$ & $0.33 \pm 0.05$ & $-0.09 \pm 0.87$ \\
\hline Copper & $2.32 \pm 0.06 *$ & $-0.46 \pm 0.02$ & $0.38 \pm 0.09$ & $0.87 \pm 0.07 *$ & $0.31 \pm 0.08$ & $-0.10 \pm 0.81$ \\
\hline Iron & $4.23 \pm 0.26^{*}$ & $-3.35 \pm 0.14^{*}$ & $4.02 \pm 0.33 *$ & $3.73 \pm 0.31^{*}$ & $9.07 \pm 0.69 *$ & $-12.51 \pm 12.20$ \\
\hline Potassium & $2.30 \pm 0.01^{*}$ & $0.28 \pm 0.00 *$ & $0.60 \pm 0.01 *$ & $0.17 \pm 0.01 *$ & $-0.37 \pm 0.01^{*}$ & $0.15 \pm 0.85$ \\
\hline Magnesium & $0.18 \pm 0.01^{*}$ & $-0.01 \pm 0.00$ & $0.28 \pm 0.01^{*}$ & $-0.04 \pm 0.01$ & $0.02 \pm 0.01$ & $0.03 \pm 0.05$ \\
\hline Zinc & $2.35 \pm 0.17^{*}$ & $-1.57 \pm 0.06^{*}$ & $0.47 \pm 0.22$ & $0.02 \pm 0.18$ & $4.45 \pm 0.38^{*}$ & $-7.24 \pm 5.41$ \\
\hline Total phenols & $153.96 \pm 1.58 *$ & $5.94 \pm 0.53^{*}$ & $27.02 \pm 2.26 *$ & $28.17 \pm 1.69 *$ & $-27.78 \pm 2.33^{*}$ & $23.16 \pm 5.11$ \\
\hline Anti. Content & $950.12 \pm 10.40^{*}$ & $-260.92 \pm 11.71 *$ & $27.62 \pm 14.96$ & $218.87 \pm 16.9 *$ & $348.43 \pm 17.43^{*}$ & $307.60 \pm 13.98$ \\
\hline
\end{tabular}


Table 5. Estimates of variance components and heritability of nutritional and antioxidant traits for the cross SM001-07 x ST004-03.

\begin{tabular}{|c|c|c|c|c|c|c|c|}
\hline Trait & VA & VD & VE & VP & VG & $h^{2} b$ & $h^{2} n$ \\
\hline Carbohydrate & 1.12 & -1.10 & 0.67 & 0.69 & 0.02 & -41.57 & 77.61 \\
\hline Dry matter & -0.11 & -0.27 & 0.38 & 0.00 & -0.38 & 49.92 & 0.14 \\
\hline Moisture & -1.27 & 0.76 & 0.22 & 0.29 & -0.51 & 39.02 & 36.84 \\
\hline Fibre & -0.02 & 0.01 & 0.86 & 0.85 & -0.01 & 22.59 & 2.07 \\
\hline Protein & 2.33 & -1.64 & 0.13 & 0.82 & 0.69 & 12.03 & 95.06 \\
\hline Copper & -1.25 & 0.56 & 0.28 & -0.41 & -0.69 & 14.00 & 50.37 \\
\hline Iron & -0.46 & 0.22 & 0.09 & 0.15 & -0.24 & 83.59 & 6.70 \\
\hline Potassium & -1.55 & 0.71 & 0.71 & 0.13 & -0.84 & 97.46 & 19.73 \\
\hline Magnesium & 0.01 & -0.01 & 0.01 & 0.01 & 0.00 & 18.39 & 0.03 \\
\hline Zinc & -0.38 & 0.23 & 0.02 & -0.13 & 0.15 & 63.90 & 4.81 \\
\hline Total phenol & -0.48 & 0.20 & 0.52 & 0.06 & -0.46 & 29.71 & 12.11 \\
\hline Anti. Content & 2.09 & 1.27 & 0.16 & 3.52 & 3.36 & 83.15 & 37.79 \\
\hline
\end{tabular}

Table 6. Estimates of variance components and heritability of nutritional and antioxidant traits of the cross SM001-07 x San005-01.

\begin{tabular}{|c|c|c|c|c|c|c|c|}
\hline Trait & VA & VD & VE & VP & VG & $h^{2} b$ & $h^{2} n$ \\
\hline Carbohydrate & -1.41 & -0.11 & 0.59 & -0.93 & -1.52 & 11.86 & 33.28 \\
\hline dry matter & -3.31 & 0.58 & 0.75 & -1.98 & -2.73 & 36.09 & 56.48 \\
\hline Moisture & -92.41 & 30.71 & 0.10 & 61.69 & 61.70 & 70.04 & 30.40 \\
\hline Fibre & 2.19 & -1.09 & 0.40 & 1.14 & 1.10 & 79.52 & 31.11 \\
\hline Protein & 1.08 & -1.16 & 0.92 & 0.84 & -0.08 & 16.30 & 92.10 \\
\hline Copper & -0.39 & -0.29 & 0.55 & -0.12 & -0.67 & 94.27 & 5.46 \\
\hline Iron & 1.84 & -1.53 & 1.22 & 1.53 & 0.31 & 56.02 & 81.61 \\
\hline Potassium & -1.18 & -0.20 & 0.85 & -0.53 & -1.38 & 2.33 & 63.87 \\
\hline Magnesium & -0.01 & -0.01 & 0.01 & -0.01 & -0.02 & 30.45 & 11.30 \\
\hline Zinc & 0.29 & -0.26 & 0.41 & 0.44 & 0.03 & 9.99 & 13.14 \\
\hline Total phenol & -1.77 & 0.14 & 0.56 & -1.07 & -1.63 & 54.41 & 91.18 \\
\hline Anti. Content & -2.47 & 0.76 & 0.06 & -1.65 & -1.71 & 27.36 & 5.90 \\
\hline
\end{tabular}

The interaction gene effects in both crosses were negative and non-significant except additive $\mathrm{x}$ additive interaction gene effect in cross SM001-07 x San005-01 (Tables 4 and 5).

For protein, the additive gene effect was negative and nonsignificant for crosses SM001-07 x ST004-03 and SM001-07 x San005-01. Though, dominance gene effect was found positive and significant (Tables 3 and 4). The interaction gene effects were non-significant.

The additive and dominance gene effect for copper was nonsignificant $(P \geq 0.05)$ in both crosses (SM001-07 x ST004-03 and SM001-07 $x$ San005-0). However, among the interaction gene effects, additive $x$ dominance and additive $x$ additive gene interaction effects were significant $(P<0.05)$ (Tables 3 and 4$)$. Negative and significant additive gene effect was recorded for iron and the dominance gene action was found positive and significant in both crosses (SM001-07 x ST004-03 and SM001$07 \times$ San005-01). Similarly, all the gene interaction effects were positive and significant, except dominance $x$ dominance gene interaction effect that showed negative and non-significant interaction effect (Tables 4 and 5).

Negative and significant main gene effects (additive and dominance gene effects), as well as additive $x$ additive, additive $\mathrm{x}$ dominance and dominance $\mathrm{x}$ dominance gene interaction effects were observed for potassium in cross SM001-07 x ST004-03, while cross SM001-07 x San005-01 was positive and significant for additive, dominance, and additive $x$ additive effects. However, the gene interaction effect of additive $\mathrm{x}$ dominance was negative and significant for the same trait (Tables 3 and 4).
For magnesium, all the gene interaction effects were nonsignificant for both crosses (SM001-07 x ST004-03 and SM001$07 \times$ San005-01). However, additive gene effect was negative and significant in cross SM001-07 $\times$ ST004-03 while the dominance gene effect was observed to be positive and significant in cross SM001-07 x San005-01 (Tables 3 and 4).

There was negative and significant additive gene effect for zinc. The dominance gene effect was found non-significant in both crosses (SM001-07 x ST004-03 and SM001-07 x San005$01)$. For gene interaction effects, only additive and dominance gene effects were observed to be significant in both crosses for this trait (Tables 3 and 4).

In the case of total phenol, the dominance gene effect was positive and significant in both crosses. However, the additive gene effect in cross SM001-07 x ST004-03 was negative and significant while a positive and significant gene effect was observed in cross SM001-07 x San005-01 (Tables 3 and 4). For the gene interaction effects, it was observed that additive $x$ additive gene interaction effect was positive and significant whereas additive $x$ dominance gene interaction effect was negative and significant in both crosses (Tables 3 and 4).

The additive $x$ additive and additive $x$ dominance effects were positive and significant only in the cross SM001-07 x San00501 for antioxidant content. The major gene effects (additive and dominance gene effects) showed significant and negative additive gene effect in both crosses, but the dominance gene effect was not significant (Tables 3 and 4). 


\section{Estimates of variance components and heritability for nutritional and antioxidant characters}

The estimates of additive, dominance and environmental components of variance, broad and narrow sense heritability for nutritional and antioxidant traits in two different crosses are presented in Tables 5 and 6 . The variance components varied for the different traits in the two crosses. The additive and dominance components ranged from 0.01 to 2.33 and 0.01 to -1.64 , respectively in cross SM001-07 x ST004-03, while a range of -0.01 to -92.41 and -0.01 to 30.71 was observed in cross SM001-07 x San005-01 (Tables 5 and 6). Further, the values recorded for additive variance for most of the nutritional and antioxidant traits were higher than the dominance variance in both crosses except for dry matter, magnesium and protein (Tables 5 and 6 ). The additive variance for protein was observed to be positive while its dominance variance was negative.

For environmental variance, crude fibre showed the largest variance (0.86) in cross SM001-07 x ST004-03, while iron recorded the highest (1.22) in SM001-07 x San005-01. The lowest environmental variance (0.01) was observed in magnesium for both crosses (Tables 5 and 6).

The result of the heritability estimates varied considerably for the various traits for the two crosses. Broad sense heritability ranged from 12.03 (protein) to $97.46 \%$ (potassium) in cross SM001-07 x ST004-03, and 2.33 (potassium) to $94.27 \%$ (copper) in cross SM001-07 x San005-03. Narrow-sense heritability ranged from 0.03 (magnesium) to $95.06 \%$ (protein) in cross SM001-07 x ST004-03, and 5.46 (copper) to $92.10 \%$ (protein) in cross SM001-07 x San005-01 (Tables 5 and 6). Moreover, in cross SM001-07 x ST004-03, high narrow sense heritability (above 70\%) estimates was recorded for carbohydrate and protein, with moderate heritability (above $30 \%)$ for moisture, copper and antioxidant content. Low heritability (below 30\%) was observed for dry matter, fibre, iron, zinc, magnesium, potassium and total phenols. Conversely, in cross SM001-07 x San005-01, iron, total phenols, and potassium recorded high narrow sense heritability. Narrow sense heritability was moderate for carbohydrate, dry matter, moisture and fibre. While low heritability was observed for antioxidant content, zinc, magnesium and copper (Tables 5 and 6).

\section{Discussion}

\section{Mean comparison for nutritional and antioxidant traits}

The significant differences observed for all the six generations in both crosses for most traits indicate the existence of genetic variability and the possibility of selecting superior genotypes to be used for the genetic improvement of eggplant. Effective selection of suitable genotypes will facilitate the introgression of desirable traits from wild eggplant into cultivated ones and thus, improve the nutritional and antioxidant traits of eggplant cultivars in Ghana. Similar observation was reported by Roychowdhury et al. (2011), Sabolu et al. (2014) and Zdravković et al. (2011) for fruit quality characters in eggplant and tomato, respectively.
The significantly high mean performance of cross SM001-07 $\mathrm{x}$ San005-01 over parents in all four generations (F1, F2, BC1 and $\mathrm{BC2}$ ) for magnesium, suggested the role of additive genes in these generations. Additive gene component of variation is very important in the improvement of crops since a superior phenotype will breed true to type in the next generation making selection effective. Therefore, for improvement of this trait, pureline or pedigree method of selection would be useful in advance generations to develop eggplant variety with high nutrient composition. This finding is in accordance with the results of Sabolu et al. (2014) in eggplant. The low F1 values recorded for most traits (with respect to either parent) could also be attributed to regression of heterosis or hybrid vigour. Although there is a general close relationship between genetic divergence and hybrid vigour (Mohan et al., 2004), sometimes the dispersion of alleles from parents occur when hybridization is carried out between two genetically opposed parents, example wild and cultivated eggplants. On the other hand, the high and low F1 mean values recorded over both parents for other traits could be explained by dominance and over dominance gene effects. When dominance is complete, the plant breeder cannot differentiate between the homozygote and heterozygote phenotypes, thus making the fixing of superior allele(s) in subsequent generations less effective. Selection of genotypes for fibre, protein, potassium, magnesium, carbohydrate, copper and antioxidant content should be delayed until a high level of fixation is attained in advanced generations as already reported by Hasanuzzaman and Golam (2011). High mean values obtained for F1 traits compared to F2 values indicated the presence of inbreeding depression whiles the absence of inbreeding depression for copper, potassium, antioxidant content, carbohydrate and dry matter suggested the possibility of obtaining transgressive segregants for these traits. Similar observation was reported by Mohan et al., 2004 and Ramabhai (2015). Further, the high mean values recorded for traits in $\mathrm{BC} 2$ generations compared to the recurrent parent (SM001-07) showed the predominance of genes for high nutritional and antioxidant content in this backcross generation. This finding is similar to the report by Sabolu (2013) who worked on fruit quality characters in eggplant using generation mean analysis.

\section{Gene action among traits}

The significantly higher magnitude of additive gene effect for the expression of fibre, magnesium, antioxidant content and carbohydrate showed the importance of additive genes in the inheritance of these traits. This indicates that the pedigree method should be followed for effective selection of segregants. The importance of additive gene effect was reported by Sabolu et al. (2014) for polyphenol oxidase activity and ascorbic acid content in eggplant. The higher magnitude of dominance gene effect for protein also showed that it would be difficult to improve this trait through direct selection. The selection of genotypes should therefore be postponed to a later segregating generations with dilution of dominance as earlier reported by Sabolu (2013) in eggplant.

The inheritance of traits was also governed by both additive and non-additive effects with the preponderance of 
dominance effect for carbohydrate, moisture, iron (SM001-07 x ST004-03) and potassium (SM001-07 x San005-01), while additive $x$ additive interaction effect controlled the inheritance of dry matter (SM001-07 x ST004-03), copper and total phenols (SM001-07 x San005-01). The improvement of carbohydrate, moisture, iron and potassium could be enhanced through population improvement approaches, followed by delayed selection in later segregating generations in both crosses. While, simple selection could be employed in the improvement of dry matter, copper and total phenols. Further, the higher magnitude of additive $\times$ dominance gene effect for copper, potassium, zinc, total phenols (SM001-07 $x$ ST004-03), dry matter, moisture, iron, zinc, antioxidant content (SM001-07 x San005-01) indicated that these traits could be improved through delayed selection and inter-mating the segregants followed by recurrent selection. The preponderance of additive $x$ dominance gene effects was also reported by Ramalingam and Sivasamy (2002), Sabolu et al. (2014) and Chakraborti et al. (2010) for total phenols, antioxidant content, zinc and iron, respectively.

\section{Variance components and heritability estimates for nutritional and antioxidant characters}

Most of the traits exhibited higher additive variance than the dominance variance in both crosses, which indicated that these traits could be improved through simple selection in early segregating generations. However, for dry matter (SM001-07 x ST004-03) and protein (SM001-07 x San005-01) which were associated with high dominance variance in relation to additive variance, population improvement approaches (example pure line) followed by delayed selection in segregating generations would be effective. Similar results were reported by Sabolu et al. (2014) in eggplant.

Environmental variance was generally low in magnitude compared to additive and dominance variances. However, dry matter, fibre, total phenols, copper, magnesium and zinc showed greater values of environmental variance compared to additive and dominance variances. This was confirmed by the low narrow sense heritability observed for these traits. Thus, the selection of genotypes for these traits should be intensive through later generations. A similar result was reported by Khattab et al. (2010). Besides, the high broad sense heritability values recorded for iron, potassium, zinc, antioxidant content (SM001-07 x ST004-03), moisture and fibre (SM001-07 $x$ San005-01) suggested that, these traits are controlled by both additive and non- additive gene effects as reported by Koundinya et al. (2017) in eggplant. Estimates for narrow sense heritability was high for carbohydrate, protein (SM001-07 $\mathrm{x}$ ST004-03), iron, potassium and total phenols (SM001-07 $x$ San005-01), which might be of great importance for both crosses. Narrow sense heritability estimates are based on additive genetic variance (fixable component) and hence gives a good prediction of the effectiveness of selection in a genetically heterogeneous population.

\section{Materials and methods}

\section{Plant materials and experimental Design}

Six basic generations (P1, P2, F1, F2 BC1 and $\mathrm{BC} 2$ ) derived from a cross between (SM001-07 (P1, cultivated) $\times$ ST004-03 (P2, wild) and another set of six generations (P1, P2, F1, F2 BC1 and BC2) from a cross between (SM001-07 (P1) $\times$ San005-01 (P2, wild) were subjected to a field experiment using experimental pots (measuring $28 \times 29 \mathrm{~cm}$ ). The experiment was carried out at the research field of the Faculty of Agriculture, Kwame Nkrumah University of Science and Technology (KNUST), Kumasi using a Randomized Complete Block Design (RCBD) in 2017. Well-developed seedlings (few tissue culture derived plantlets) were transplanted into pots containing sterile black soil $(4 \mathrm{~kg}$ ) at spacing $60 \mathrm{~cm} \times 60 \mathrm{~cm}$, with four plantlets per generation and four replications. In all a total number of 96 plantlets per cross from all the six generations were grown. All cultural practices; fertilizer application, irrigation and weed control were carried out. Freshly harvested fruits (immature fruits with shinny peels) were harvested from these plants and subjected to nutritional and antioxidant analyses.

\section{Data collection}

\section{Proximate analysis}

Proximate analysis was carried out using the AOAC (1990) standard methods. Moisture was determined by drying a representative $5 \mathrm{~g}$ chopped fruits (sample) in an oven (Gllenkamp, England) at $105^{\circ} \mathrm{C}$ until constant weight. Ash content was determined by the incineration of fruit sample $(2 \mathrm{~g})$ in a muffle furnace (Lenton, England) at $550^{\circ} \mathrm{C}$ for $4 \mathrm{hrs}$ until the ash turned white. Crude protein was assessed by the Kjeldahl method using the value of 6.25 as conversion factor of nitrogen to protein. Lipid content was evaluated by hexane extraction for $7 \mathrm{hrs}$ in a Soxhlet apparatus. For crude fibre content, $2 \mathrm{~g}$ of dried powdered sample were digested with $0.25 \mathrm{M}$ sulphuric acid and $0.3 \mathrm{M}$ sodium hydroxide solution. The insoluble residue obtained was washed with hot water and dried in an oven (Gllenkamp, England) at $100^{\circ} \mathrm{C}$ until constant weight. The dried residue was then incinerated and weighed for the determination of crude fibre content. Carbohydrate content was calculated using the formula (FAO, 2002): Carbohydrates: $100-(\%$ moisture $+\%$ protein $+\%$ lipid $+\%$ ash $+\%$ fibre).

\section{Mineral analysis}

One gram (1g) of fine powdered sample from each fruit accession was digested following wet digestion procedures using concentrated $\mathrm{HNO}_{3}$ and $30 \% \mathrm{H}_{2} \mathrm{O}_{2}$. The digested samples were used for elemental analysis. Iron (Fe), Copper ( $\mathrm{Cu}$ ), Manganese ( $\mathrm{Mn}$ ) and Zinc ( $\mathrm{Zn})$ were determined using Atomic Absorption Spectrophotometer while Sodium (Na), Potassium $(K)$, Phosphors $(P)$ was determined by vanadomolybdate (430 $\mathrm{nm}$; Jenway 6051 calorimeter) and Calcium (Ca) were evaluated using Flame photometer. 


\section{Antioxidant analysis}

The total phenols content was determined using the FolinCiocalteu assay (Macdonald et al. (2001) using gallic acid as standard. The total antioxidant capacity of the methanol extract was evaluated by the phosphomolybdenum method according to the procedure described by Prieto et al. (1999) while the DPPH (1, 1-diphenyl-2 picrylhydrazyl) method was used to determine the free radical scavenging activity (Mensor et al., 2001).

\section{Data analysis}

All data were subjected to Analysis of Variance using GenStat statistical package, $11^{\text {th }}$ edition. Generation mean analysis was also employed to estimate the gene effect of the different parameters (proximate, mineral and antioxidant traits), using Plant Breeding Tools (PBT), version 1.4. (2014). Variance components (additive, dominance and environment) were estimated as described by Mather and Jinks (1982) using the following equations:

$\mathrm{VA}=4 \mathrm{VF} 2-2(\mathrm{VBC} 1+\mathrm{VBC} 2)$

$\mathrm{VD}=4(\mathrm{VB1}+\mathrm{VB} 2-\mathrm{VF} 2-\mathrm{VE})$

$\mathrm{VE}=0.25(\mathrm{VP} 1+\mathrm{VP} 2+2 \mathrm{VF} 1)$

Where, $\mathrm{VA}=$ additive variance, $\mathrm{VD}=$ Dominance variance and $\mathrm{VE}=$ environmental variance.

Broad-sense $\left(h^{2} b\right)$ and narrow-sense $\left(h^{2} n\right)$ heritability were calculated using the following equations by Mather and Jinks (1982):

$\left.\mathrm{h}^{2} \mathrm{~b}=\{[\mathrm{VF} 2-(\mathrm{VP} 1+\mathrm{VP} 2+2 \mathrm{VF} 1) / 4)] / \mathrm{VF} 2\right\}$

$h^{2} n=[V F 2-(V B C 1+V B C 2) / 2] / V F 2$.

\section{Conclusion}

The significant differences among generations for almost all the traits under study showed the presence of sufficient genetic variation among the eggplant population to ensure effective selection for traits of interests. The average nutrient concentration of progenies for magnesium was significantly higher than that recorded for both parents. This indicates genetic introgression of nutrient in these progenies. Additive and non-additive effects controlled the inheritance of dry matter, moisture, iron, potassium, zinc and total phenols with the preponderance of dominance gene effect. Therefore, to improve these traits, population improvement approaches (recurrent selection or pure line) followed by delayed selection in segregating generation would be beneficial.

\section{Acknowledgement}

Financial assistance from Ghana Atomic Energy Commission is gratefully acknowledged.

\section{References}

AOAC (Association of Official Analytical Chemists), (1990) Official methods of analysis. Association of official analytical chemists, inc. Arlington, Virginia.
Arora D, Jindal SK, Ghai TR (2010) Quantitative inheritance for fruit traits in inter-varietal crosses of okra (Abelmoschus esculentus L. Moench). Electron J Plant Breed. 1: 1434-1442.

Boeing $H$, Bechthold A, Bulb A, Ellinger S, Haller D, Kroke A, Leschik-Bonnet E, Muller MJ, Oerritter H, Schulze M (2012) Critical review: vegetables and fruits in prevention of chronic diseases. Eur J Nutr. 51: 637-663.

Chakraborti M, Prasanna BM, Singh AM, Hossain F (2010) Generation mean analysis of kernel iron and zinc concentrations in maize (Zea mays). Indian J Agr Sci. 80 (11): 956-9.

Deb AC, Khaleque MA (2009) Nature of gene action of some quantitative traits in chickpea (Cicer arietinum L.). World J Agri Sci. 5 (3): 361-368.

Denton OA, Nwangburuka CC (2011) Genetic variability in eighteen cultivars of Solanum anguivi Lam. using principal component analysis and single linkage cluster analysis. Ann Biol Res. 2 (4): 62-67.

Deshmukh SB, Sawant SN, Narkhede, GW, Dod VN (2014) Gene action studies in brinjal (Solanum melongena). Middle-East J Sci Res. 21 (11): 2177-2181.

FAO (Food and Agriculture Organization of the United Nations, Rome) (2002) Food energy-methods of analysis and conversation. Report on technical workshop, Rome 3-6 December, 2002. FAO Food Nutr. 77: 58-59.

Hasanuzzaman M, Golam F (2011) Gene actions involved in yield and yield contributing traits of chilli (Capsicum annuum L.). Aust J Crop Sci. 5 (13): 1868-1875.

Kearsey MJ, Pooni HS (1996) The genetical analysis of quantitative traits. Chapman and Hall publishers, New York.

Khattab SAM, Esmail RM, Rahman A (2010) Genetical analysis of some quantitative traits in bread wheat (Triticum aestivum L). NY Sci J. 3 (11): 152-157.

Koundinya AV, Das V, Layek A, Chowdhury SR, Pandit MK (2017) Genetic variability, characters association and path analysis for yield and fruit quality components in brinjal. J Appl Nat Sci. 9 (3): 1343-1349.

Lobo V, Patil A, Phatak A, Chandra N (2010) Free radicals, antioxidants, and functional foods: impact on human health. Phcog Rev. 4: 118-126.

Mcdonald S, Prenzler PD, Autolovich M, Robards K (2001) Phenolic content and antioxidant activity of olive oil extracts. Food Chem. 73: 73-84.

Mather K, Jinks JL (1982) Biometrical genetics: the study of continuous variation (third edition). Chapman and Hall Inc., London- New York.

Mensor LI, Menezes FS, Leitao GG, Reis AS, Dos Santos T, Coube CS, Leitao SG (2001) Screening of Brizilian plant extracts for antioxidant activity by the use of 1,1-diphenyl-2picrylhydrazyl free radical method. Phytother Res. 15: 127130.

Mohan RG, Lakshmikantha R, Kulkarni RS, Ramesh S, Reddy SSL (2004) Prediction of heterosis based on genetic divergence of parents through regression analysis in sunflower (Helianthus annuus L.). Helia. 27 (41):51-58.

Prieto P, Pineda M, Anguilar M (1999) Spectrophotometric quantitation of antioxidant capacity through the formation of a phosphomolybdenum complex: Specific application for the determination of vitamin E. Anal Biochem. 269: 337-341. 
Ramalingam A, Sivasamy N (2002) Genetics and order effects of seed cotton yield in upland cotton (Gossypium hirsutum L.) triallel analysis. Indian J Genet Plant Breed. 62 (4): 359360.

Ramabhai MR (2015) Genetic analysis of morpho-physiological traits in rice (oryza sativa L.) Master thesis, Navsari Agricultural University, p. 1-174.

Roychowdhury R, Roy S, Tah J (2011) Estimation of heritable components of variation and character selection in eggplant (Solanum melongena L.) for mutation breeding programme. Cont J Biol Sci. 4 (2): 31-36.

Sabolu S (2013) Generation mean analysis for fruit quality determining characters in brinjal

(Solanum melongena L.). Aust J Crop Sci. 8 (2): 243-250.
Sabolu S, Kathiria KB, Mistry CR, Kumar S (2014) Generation mean analysis of fruit quality traits in eggplant (Solanum melongena L.). Aust J Crop Sci. 8 (2): 243-250.

Singh RP, Singh S (1992) Estimation of genetic parameters hrough generation mean analysis in bread wheat. Indian J Genet Plant Breed. 52: 369-375.

Sumanth V, Suresh BG, Jalandhar BR, Srujana G (2017) stimation of genetic variability, heritability and genetic advance for grain yield components in rice (Oryza sativa L.). J Pharmacogn Phytochem. 6 (4): 1437-1439.

Zdravković J, Pavlović N, Girek Z, Brdar-Jokanović M, Savić D, Zdravković M, Cvikić D (2011) Generation mean analysis of yield components and yield in tomato (Lycopersicon esculentum mill.). Pak J Bot. 43 (3): 1575-1580. 